\title{
The Development of Transformation Geometry Learning Medium with Scientific Approach As Effort to Improve the Understanding Concept Skill
}

\author{
Agung Wirapathi \\ Ganesha University of Education \\ gustiwira42@gmail.com \\ Made Candiasa \\ Ganesha University of Education \\ candiasaimade@yahoo.co.id \\ Pasek Suryawan \\ Ganesha University of Education \\ pasek.suryawan@yahoo.co.id
}

\begin{abstract}
The development research aims to describe: (1) storyboard; (2) the implementation results; and (3) the usability of the transformation geometry learning medium with scientific approach. The development uses 4-D model which consisting of define, design, develop, and disseminate, but this research is only up to the develop step. The results showed that the transformation geometry learning medium with scientific approach can be accepted as a learning medium with very valid category, which seen from the validity score is 4.37. Learning medium developed got excellent response with the average score of practicability is 4.5 . This learning medium also has a high effectiveness in learning process with the level of student activity reached the average score around 4.2 , and the classical completeness is $80 \%$. Based on the result of the research, it's expected that the transformation geometry learning medium with scientific approach can be used in learning process.
\end{abstract}

Keywords: learning medium, transformation geometry, 4-D

\section{Introduction}

Learning process is a system that aims to assist the learning process of students, which contains a series of events designed, arranged in such a way as to support and influence the occurrence of internal learning processes of students (Aunurrahman, 2012). Learning or learning process includes the interaction between educators with students and other learners to achieve a goal, namely changes in attitude and students behaviour. The most important thing in teaching and learning activities is the process, in which the process will determine whether the learning goals are achieved or not. Achievement of learning goals can be seen from the presence or absence of behavioural changes. Both changes are cognitive, affective, and psychomotor.

Learning goals are more easily achieved when the lessons are going in effective ways. Effective learning is characterized by the occurrence of learning in the learner, which is a change from not know yet become know, from not understand become understand, and so forth. But in fact, most of learning process are going in less effectively, so the learning goals are not fully achieved.

The government has tried to fix the problems that occur in learning process, especially related to ineffective learning. One of the efforts that has been done by the government is implemented the 2013 curriculum. 2013 Curriculum is a series of improvements to the curriculum that has been pioneered before, which are Competency Based Curriculum in 2004 which then continued with Education Unit Level Curriculum in 2006. Typical of the 2013 curriculum's existence is scientific approach application in learning process. The purpose of scientific approach's implementation is making passive students to become active in learning process.

The scientific approach is very suitable in mathematical learning process. The scientific approach encourages mathematics learning process in the scientific context and student activities. This approach links between mathematics with something happening around the students. Besides the learning process is active students also learn mathematics in interesting way. Active and interesting math learning will encourage students to engage in learning process. In other words, good learning ways of math is experienced or engaged. Learning by activities will contribute to understanding of students' mathematical concepts.

Embedding mathematical concepts to students is not an easy thing. Though the scientific approach has been applied, there's still a lot of time and energy wasted, whereas learning goals are only half achieved or not even achieved at all, especially for materials that need visualization such as transformation geometry. This is happened because the transformation geometry concept is not just counting, so to learn it takes a lot of time. Based on interviews with some mathematics teachers that students have difficulty in learning mathematics especially transformation geometry material. In addition to the students' lack of interest, teachers must submit the material 
repeatedly in order to the students can understand due to lack of tools that can assist students in understanding the subject matter. Transformation geometry material requires visualization, that's why certainly causes a lot of wasted time, whereas learning goals are not achieved. Students are required to have a high abstraction power, for example in determining the reflection of an object after being transformed. It's not enough if only using direct explanation formula, but rather a more concrete explanation. That's how the process of the occurrence of such transformation. Concrete explanations must be followed by students' activeness in exploring. For example in determining the reflection of an object after it's reflected on a straight line. Teachers can ask students to try it directly by drawing graphs, and predict where the object reflection is. Students can't precisely determine the location of the object reflection because there are several errors in determining the scale.

Regarding the limited methods and approaches applied in transformation geometry learning process, a device is required. These devices can take advantage of emerging technologies, such as learning mediums. The learning medium's usability ha more value and should be used. According to the opinion of Angkowo and Kosasih (in Musfiqon, 2012: 32), one of the learning medium's function is a learning tool that also influences the situation, condition, and learning environment in order to achieve the learning goals that have been created and designed by teachers.

Knowing the learning medium's usability, researchers developed an preliminary medium by using GeoGebra for translation material. This activity is expected two things. 1) The GeoGebra medium can attract students' attention in learning translation concept with the visualizations displayed. Students are assisted in imagining how the translation process is, so it's much easier in determining the translations reflection of a point without memorize the formula. 2) GeoGebra medium can be facilitate the implementation of learning process.

When the learning medium already developed, the researchers conduct trials on a group of students. Based on this activity, the researchers knows that GeoGebra medium is very useful in learning process. It's seen from the expected results in preliminary medium development is achieved. In addition, researchers also know that there's still many students who are afraid of making wrong answer, so the students' opportunities to explore something is reduced. It's seen from the absence of students who want to answers the results of translation reflection in front of the class.

The conclusion can be drawn from activity above is teaching the transformation geometry material must be balanced by visualization, so the students can understand the concept better. Suppose that in determining the reflection result of transformation, the student have to know how the reflection process is. Besides that, in learning process, the students should be given a chance to explore something without any fear of wrong answer. Based on that statement, it's necessary to have a learning medium that help to teach the transformation geometry material that can accommodate it.

Learning medium has been developed before, especially based on information technology. For example in the research of Ni Wayan Karmila Putri (2015) entitled "Pengembangan Medium Pembelajaran Transformasi Berbasis Geogebra"; Retni Paradesa (2016) entitled "Pengembangan Bahan Ajar Geometri Transformasi Berbasis Visual"; and A. A. GD Putra Arjawa (2017) entitled "Pengembangan Multimedia Pembelajaran Materi Garis dan Sudut Untuk SMP Kelas VII". All of those research are using GeoGebra as exploration medium. The learning medium development has met valid, practical and effective criteria. The learning medium is suitable to use in learning process. In general, the learning medium is only used as a complement in learning process. There's still need to be added some several aspects such as: (1) the learning medium can stand alone, it means that students can use the learning medium without being guided by an educator; (2) exploration facilities are provided; (3) adapted with 2013 curriculum. Resolving the shortcomings of the existing learning medium, it's deemed necessary to develop a learning medium based on a scientific approach as applied in 2013 curriculum.

The important point in 2013 curriculum is carrying out the learning process with a scientific approach which creates active learning process. The scientific approach are: (1) Observing; (2) Questioning; (3) Collecting Information; (4) Associating; (5) Communicating. By applying a scientific approach, the developed learning medium will be able to use independently by students because it's equipped with exploration facilities. But it doesn't rule out the learning medium used as a complement in learning process. Learning medium with scientific approach can be made by combining some software that's Camtasia Studio which is a software to make learning video which is equipped with screen recording facility to record ongoing activity on laptop or computer; GeoGebra which is an open source math application with a special design that includes geometry and algebra to facilitate mathematics learning process, especially on exploration slide; Adobe After effect is an animation creating software that will be input into the learning video; and Lectora Inspire as a layout application which is used as IT-based learning products development. Based on the explanation above, it's deemed necessary to conduct a research entitled "The Development of Transformation Geometry Learning Medium with Scientific Approach as Effort to Improve the Understanding Concept Skill".

\section{Method}

This research type is Research and Development. It can be defined as a research method that aims to find, improve, develop, produce products, test products, to produce a standardized product with established indicators (Yuberti, 2014). This research is using 4-D model which is developed by Thiagarajan et al. (1974), which consists 
of: (1) define; (2) design; (3) develop; and (4) disseminate, but the research is limited until develop step. At define step conducted preliminary analysis by analysing the faced problems which happened in learning process. This activity was conducted by interviewing several math teachers and carrying out the preliminary medium development, then it's tested in a group of students. After that researchers analyse the material limitations which faced in curriculum. The results of these activities are used to construct the storyboard.

Design step is a step to prepare the storyboard. The existence of storyboard will facilitate the process of making a learning medium. Besides the storyboard, at this step also prepared an instruments evaluation tool which validated before used. Instruments are something that can be used to facilitate a person when achieving goals effectively and efficiently ways (Arikunto, 2012). The instruments in this research are: (1) Learning Medium Validation Questionnaires; (2) Student and Teacher Response Questionnaires; (3) Student Activity Observation Sheet; and (4) Evaluation Tests.

The storyboard that has been compiled before will be implemented into a transformation geometry learning medium with scientific approach. Learning medium that have been formed is evaluated through several stages, namely: (1) validity test conducted by material experts and media experts; (2) product revisions; and (3) a limited trial of randomly chosen student groups.

\section{Result and Discussion}

After going through the development step, transformation geometry learning medium with scientific approach has been evaluated. Learning medium is produced from the storyboard implementation. Storyboard in this research arranged in a simple, clear, and contains several things, among others: (1) core competence and basic competence; (2) material learned item; (3) description of activities on each page; (4) the components contained in each page; (5) layout design of each page; 6) flowchart.

Table 1. One of the Learning Medium Storyboard

\begin{tabular}{|c|c|c|c|c|c|}
\hline Description & Component & Desig & & & \\
\hline a. Main Page & - Navigation button: & & & & \\
\hline There are several & home, help, exit & JUDUL MEDIA PEMBELAJARAN & HOME & HELP & EXIT \\
\hline & material evaluation & KIIKD & & & \\
\hline & enrichment, about us & SUB-BAB & & & \\
\hline & - $\quad$ Back sound: Sea Stock - & EVALUASI & & & \\
\hline & Carefree Ukulele & PENGAYAAN & & & \\
\hline & & $\begin{array}{c}\text { TENTANG } \\
\text { KAMI }\end{array}$ & & & \\
\hline
\end{tabular}

Learning medium storyboard is implemented into Prototype I by using computer application. Preparation learning medium in this case are using GeoGebra, Camtasia Studio, Adobe After Effect, and Lectora Inspire. Broadly speaking, in transformation geometry learning medium with scientific approach there are learning video, subject matter, exploratory medium and exercise which composed of several pages.

Homepage consists of several menus, namely: 1) KI / KD that contains core competencies and basic competencies; 2) Topik that contain several submenus that represent the topic of transformation geometry material; 3) Evaluasi contains some questions for exercise; 4) Pengayaan that contains additional knowledge for students which some material that isn't included into transformation geometry material for high school students; and 5) Tentang Kami (About Us). 


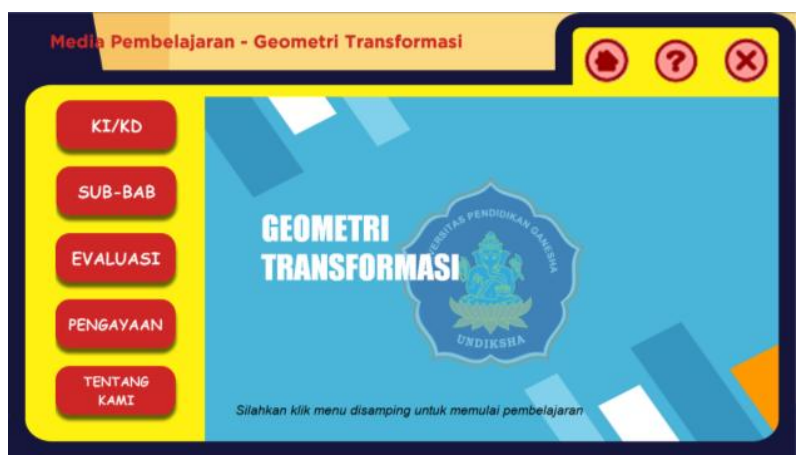

Figure 1. Homepage Views

In each topic's page there are learning videos that related to transformation geometry events that occur around, as well as some menus are: (1) Materi which is contained Material; 2) Eksplorasi which is contained GeoGebra medium; 3) Contoh Soal \& Pembahasan which is contained Question Example and Discussion.

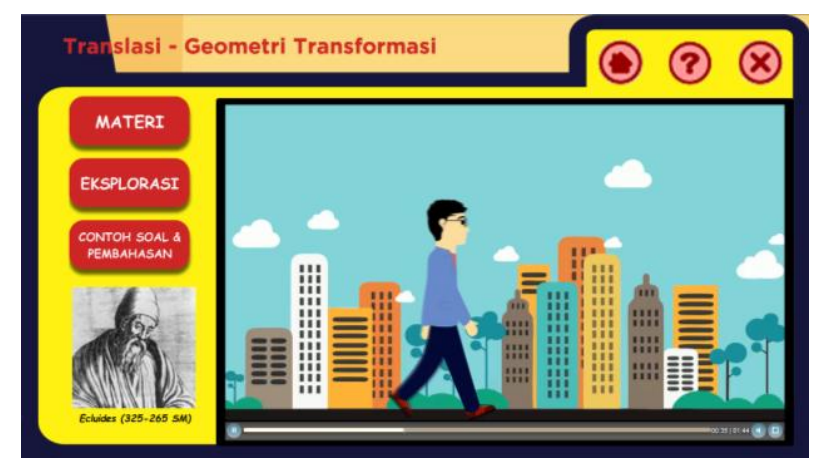

Figure 2. One of Topic Page Views

The exploratory medium of each geometry transformation topic consists of several parts, which can be accessed through the menu buttons which already provided. If once the menu button is clicked, then a new window will appear which is containing GeoGebra.

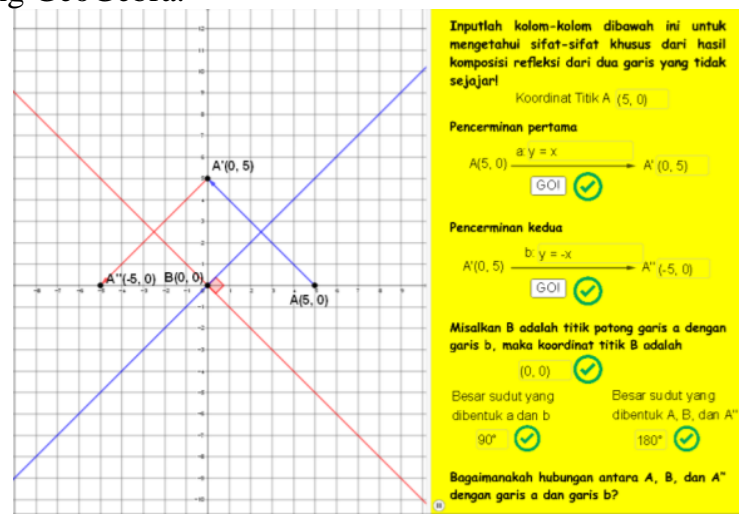

Figure 3. One of the Exploration Page Views

A learning medium is qualified if the product meets the valid, practical, and effective criteria (Nieveen, 1999). That's why the learning medium should be evaluated in order to meet valid, practical, and effective criteria. The score of transformation geometry learning medium with the scientific approach is 4.25 from the medium expert and 4.5 from the material experts. Based on the criteria with 5 scale, the medium is categorized as very valid. Recapitulation of validity results can be seen in Table 2 .

Table 2. Recapitulation of Validity Results

\begin{tabular}{ccc}
\hline Numb. & Validity & Score \\
\hline 1. & Medium & 4,25 \\
2. & Material & 4,5 \\
\hline
\end{tabular}


Learning medium that has been categorized valid and then tested its practicality and effectiveness on limited trial. The results of a limited trial conducted on 15 students, showed the transformation geometry learning medium with scientific approach obtained the average practicality score which based on the student's response questionnaire is 4.4 which is very high category based on the criteria with 5 scale. The same thing is also found in practicality of teacher response questionnaire analysis result is 4.5 which is very high category based on the criteria with 5 scale. This shows that the practicality of transformation geometry learning medium with scientific approach in very high level of practicality. Recapitulation of student and teacher response as a whole can be seen in Table 3.

Table 3. Recapitulation of Student and Teacher Response

\begin{tabular}{ccc}
\hline Numb. & Response & Score \\
\hline 1. & Students & 4,4 \\
2. & Teacher & 4,5 \\
\hline
\end{tabular}

In addition to seeing the practicality, limited trial activities also aims to determine the effectiveness of developed learning medium. The effectiveness criteria is related to the observation sheet of student activeness when they are using learning medium. The result of student activeness observation sheet analysis is very high that reached score 4.2 based on the criteria with 5 scale. Recapitulation of student activeness observation sheet analysis is presented in Table 4.

Table 4. Recapitulation of Student Activeness Observation Sheet Analysis

\begin{tabular}{ccc}
\hline Numb. & Response & Score \\
\hline 1. & Score & 630 \\
2. & Average & 4,2 \\
3. & Criteria & Very High \\
\hline
\end{tabular}

The effectiveness criteria is also related to the results of evaluation test. It's showed that the classical completeness is $80 \%$ with a total passed students is 12 . The result of the preliminary test is showed their average score is 46 , but after they are used the transformation geometry learning medium with scientific approach, their average score become 76. Recapitulation of final students score can be seen in Table 5.

Table 5. Recapitulation of Final Students Score

\begin{tabular}{ccc}
\hline Numb. & Variation & Data \\
\hline 1. & Average & 76 \\
2. & Highest Score & 86 \\
3. & Lowest Score & 62 \\
4. & Total of Passed Students & 12 \\
5. & Total of Unpassed Students & 3 \\
6. & Classical Completeness & $80 \%$ \\
\hline
\end{tabular}

Based on the results above, this research are in line with Ni Wayan Karmila Putri's research (2015) entitled "Pengembangan Media Pembelajaran Trasnformasi Berbasis GeoGebra", in terms of: (1) storyboards are arranged clearly and simply; (2) storyboard implementation is a learning medium; and (3) the learning medium is categorized as valid, practical, and effective. Besides that, transformation geometry learning medium with scientific approach has been referring to the mathematical concepts understanding indicators based on NCTM (2000) that is: (1) describe concepts in their own words which is already accommodated in the learning medium precisely at the end of the learning video; (2) identify or give example and non-example of concepts which is accommodated in the learning video; (3) use concept correctly in a variety of situations which already accommodated in GeoGebra exploration medium and the evaluation menu.

The learning medium has met valid, practical and effective criteria so it's suitable to use. However, before it can be used, this learning medium needs to go through a broader pilot phase of field testing through experimental research and needs to be passed in the last step of development model (dissemination steps) which is involving more than one School. 


\section{Conclusions}

The result of this research is transformation geometry learning medium with scientific approach. It's designed to be utilized by students in learning transformation geometry material. It's storyboard arranged in a simple, clear, and contains several things, among others: 1) core competence and basic competence; 2) items of material learned; 3) description of activities on each page; 4) the components contained in each page; 5) design the layout of each page; 6) flowchart. The storyboard implemented into a learning medium which equipped learning video, subject matter, exploratory medium and exercise. This learning medium evaluated and met valid, practical and effective criteria so it's suitable to use.

The suggestions that can be given are: (1) teachers are encouraged to utilize developed learning medium in order to support computer-based learning; (2) students are advised to use developed learning medium in transformation geometry learning process; (3) other researchers which is interested to continuing this research, suggested to try the disseminate step.

\section{Acknowledgement}

During the research process, researchers got a lot of help, input, guidance, and support from various parties. Through this opportunity, researcher would like to say thanks' to: (1) Prof. Dr. I Made Candiasa, M.I.Komp., as a first mentor who always provide guidance, direction, encouragement, and spirit; (2) I Putu Pasek Suryawan, S.Pd., M.Pd., as a second mentor who always provide guidance, direction, encouragement, and spirit; (3) I Wayan Sudra Astra, S.Pd., M.Pd., as the headmaster of SMA Negeri 1 Gianyar who has given the researching permission in SMA Negeri 1 Gianyar; (4) teachers and students of SMA Negeri 1 Gianyar who helped during the research process; (5) other parties that can't be mention one by one.

\section{References}

Arikunto, S. 2012. Dasar-Dasar Evaluasi Pendidikan Edisi 2. Jakarta: PT Bumi Aksara.

Arjawa, A. A GD Putra. 2017. Pengembangan Multimedium Pembelajaran Materi Garis dan Sudut Untuk SMP Kelas VII. Essay (unpublished). Jurusan Pendidikan Matematika, Undiksha Singaraja.

Aunurrahman. 2012. Belajar dan Pembelajar. Bandung: Alfabeta.

Musfiqon. 2012. Pengembangan Medium \& Sumber Pembelajaran. Jakarta: Prestasi Pustaka.

NCTM. 2000. Mathematics Assesment a Practical Handbook for Grades 6-8. United States of America: NCTM.

Nieveen, Nienke dan J. van den Akker. 1999. Design Approaches and Tools in Education and Training. Dordrecht: Kluwer Academic Publishers.

Paradesa, R. 2016. "Pengembangan Bahan Ajar Geometri Transformasi Berbasis Visual”. Jurnal Pendidikan Matematika RAFA, Volume 02, Nomor 01, ISSN: 2460 - 8718.

Putri, Ni Wayan Karmila. 2015. Pengembangan Medium Pembelajaran Transformasi Berbasis Geogebra. Essay (unpublished). Jurusan Pendidikan Matematika, Undiksha Singaraja.

Thiagarajan, Semmel, dkk. 1974. Instructional Development for Training Teacher of Exceptional Children. Minesota: Indiana University.

Yuberti. 2014. "Penelitian dan Pengembangan yang Belum Diminati dan Perspektifnya". Jurnal Ilmiah Pendidikan Fisika 'Al-Biruni, Volume 03, Nomor 02, ISSN: 2303 - 1832. 